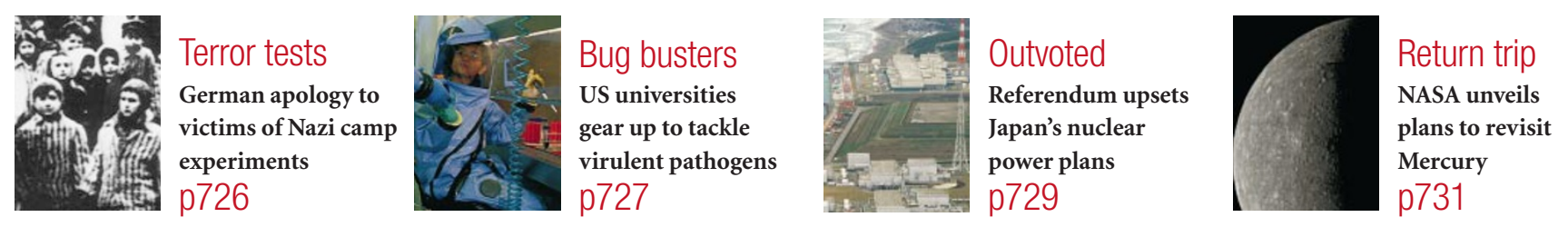

\title{
Bush set to clash with European leaders over carbon emissions
}

Irwin Goodwin, Washington

On his first visit to Europe as president, George W. Bush will tell European leaders this week that he will not accept mandatory limits on carbon emissions. He remains unmoved on the issue despite fresh confirmation from the US National Academy of Sciences that such emissions are probably responsible for global warming.

On 11 June Bush announced that he would support a new research initiative "to study areas of uncertainty and identify priority areas where investment can make a difference". He also proposed "a joint venture with the European Union, Japan and others to develop state-of-the-art climate modelling".

But Bush sought to shift the blame from the United States, which has $5 \%$ of the world's population but produces about $25 \%$ of all carbon emissions. "Our approach must be based on global participation, including that of developing countries whose net greenhouse-gas emissions now exceed those in developed countries," he said.

The academy study was requested by the White House last month (see Nature 411,255; 2001), and was chaired by Ralph Cicerone, chancellor of the University of California, Irvine. It found that the conclusion of the Intergovernmental Panel on Climate Change (IPCC) - that the global warming over the past 50 years is probably the result of increases in greenhouse gases - "accurately reflects the current thinking of the scientific community".

But the academy said that the summaries of IPCC reports placed less emphasis on uncertainty than the reports themselves, and suggested changes to the IPCC process.

The White House has been trying to ease worries about the official US stand on global warming. After rejecting the Kyoto Protocol on climate change in March, Bush set up a cabinet task force on the issue, headed by Vice-President Richard Cheney and Bush's national security adviser, Condoleezza Rice.

Just before the academy released its report on 6 June, Cicerone and panel member Sherwood Rowland briefed White House and state officials on its contents. Cheney and Rice then met with environmentalists to sketch out their plans for addressing climate change.

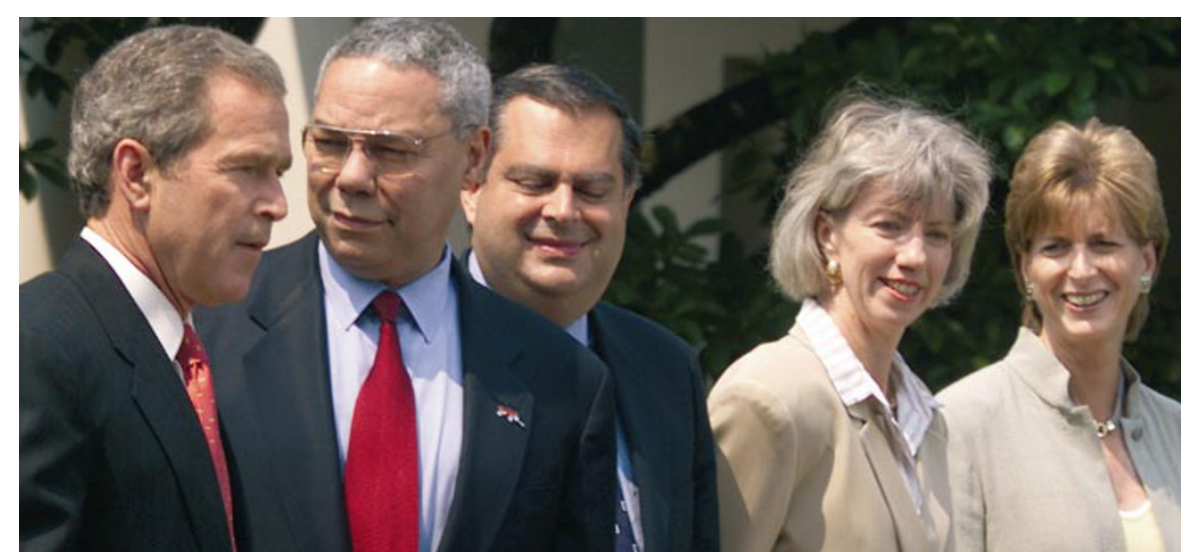

Warming up: cabinet members look on as Bush confronts climate change ahead of his visit to Europe.

"They are weighing very heavily what to do at home before deciding what to do abroad," says Eileen Claussen, president of the Pew Center on Global Climate Change, who attended one of these meetings.

A Bush spokesman says the academy report provided "a basis of sound science on which decisions can be made", adding that "the president agrees action has to be taken".
But Don Ritter, a former Republican congressman who now heads the National Environmental Policy Institute in Washington, says that the academy report may prove embarrassing for Bush. He says: "The president probably never heard of Seneca, the Roman philosopher, who said: 'Do not ask for what you will wish you had not got'.” http://www.nas.edu

\section{Labs seek share of NIH spending}

Meredith Wadman, Washington

Senior advisers to the National Institutes of Health (NIH) have called for a billion dollars a year to be spent on construction and renovation of biomedical research labs.

The proposed investment would dwarf the \$75 million that Congress earmarked for construction from the biomedical agency's 2001 budget of $\$ 20$ billion. But advocates of the change say that a boost in such spending is needed if research infrastructure is to keep pace with the doubling of the overall NIH budget between 1999 and 2003.

The recommendation was delivered in a report to acting NIH director Ruth Kirschstein on 7 June by a group commissioned in 1999 by outgoing NIH director Harold Varmus.

The group says that existing construction funding cannot keep pace with recent large increases in NIH funding for researchers. "We wanted ...s people [to] understand you can't do research in a garage," says William Brody, president of Johns Hopkins University, who chaired the group.

But NIH officials fear that Congress may respond to the request with money that the NIH could otherwise spend on grants to researchers. "If there was to be interest in putting more money in construction ... then they might try to find it somewhere else [in the NIH]," notes Kirschstein. She deferred a decision on the group's findings until the committee meets again in December.

Academic medical centres in the United States customarily pay for new laboratories themselves, hoping to recoup some of their costs from government grants. 